https://doi.org/10.18485/iipe_euchanges.2021.ch2

\title{
STRENGTHENING SECURITY AND DEFENCE - WHAT IS THE RELATIVE POWER OF THE EUROPEAN UNION VIS-À-VIS THE MEMBER STATES?
}

\author{
Miroslav GLIŠIĆ ${ }^{1}$ \\ Branislav ĐORĐEVIĆ ${ }^{2}$ \\ Dejan STOJKOVIĆ ${ }^{3}$
}

\begin{abstract}
The implementation process of A Global Strategy for the European Union's Foreign and Security Policy has triggered significant dynamism into the security and defence domain. This paper deals with the research question of how strengthening the European Union security and defence affects possible shifting preferences between supranationalism and intergovernmentalism. The authors analyse new initiatives and tools launched to strengthen the European Union's cooperation on defence and integration in the defence domains well as the role of the European Union and the Member States in these processes. The tested general hypothesis within this research is the following: Despite the importance of ongoing strengthening of the European Union's cooperation on defence and integration in the defence domain, the development process of almost all new initiatives and tools in this domain is in the hands of the Member States. Taking into consideration the above-mentioned, this paper seeks to explain how the Member States are central decision-makers within the processes
\end{abstract}

\footnotetext{
${ }^{1}$ Ministry of Defence, Belgrade, Serbia. E-mail: miroslav.glisic@gmail.com

${ }^{2}$ Full Professor, Director of the Institute of International Politics and Economics, Belgrade, Serbia. E-mail: bdjordjevic@diplomacy.bg.ac.rs

The paper presents findings of a study developed as a part of the research project "Serbia and challenges in international relations in 2021", financed by the Ministry of Education, Science, and Technological Development of the Republic of Serbia, and conducted by the Institute of International Politics and Economics, Belgrade.

${ }^{3}$ Associate Professor, Defence University, Ministry of Defence, Belgrade, Serbia. E-mail: dej.stojkovic@gmail.com
} 
related to the defence matters within the European Union. Using the Intergovernmentalist Theoretical Framework, it can be concluded that strengthening the European Union's cooperation on defence and integration in the defence domain is the product of bargains amongst member countries that is driven by the domestic policy while supranational institutions have limited importance. The content analysis method in this paper is based on the documents and academic articles mainly related to the defence matters within the European Union and the EU's Global Strategy.

Keywords: European Union, Intergovernmentalism, Supranationalism, Intergovernmentalist Theoretical Framework, the EU's Global Strategy, the Common Security and Defence Policy, the EU'scooperation on defence and integration in the defence domain.

\section{INTRODUCTION}

Parallel with the implementation process of A Global Strategy for the European Union's Foreign and Security Policy (the EU's Global Strategy) adopted in June 2016, strengthening the European Union's cooperation on defence and integration in the defence domain is becoming more and more important and represents a very useful game-changer within European defence and security matters, as well as within the European agenda for cooperation as a whole. From this point of view, the paper gives primacy to the EU's cooperation on defence and integration in the defence domain over the Common Security and Defence Policy. Consequently, this paper focuses mainly on discussing defence matters rather than security matters even though it isnot easy to find literature devoted only to European defence without mentioning security and defence together (Marambanyika, 2018, pp. 1-3).

There are a lot of significant unanswered questions about the genesis of European Integration, and one of them is clearly raised by Erdem (Erdem, 2006, p. 1) - 'To what extent European nation-states gave power vis-à-vis the EU, in other words, what is the relative power of the EU vis-à-vis the Member States?' Considering the topic and scope of his paper, Erdem did not elaborate further on the posed questionand left this to other scholars. This paper attempts to answer the mentioned question considering the most important taken decisions and launched initiatives related to the European Union's cooperation on defence and integration in the defence domain during the period from 2013 to 2020 using the Intergovernmentalist Theoretical Framework. 
In line with the scope and research aim of this paper, the Intergovernmentalist Theoretical Framework consists of Intergovernmentalist theory, Liberal Intergovernmentalist theory and New Intergovernmentalist theory with assumptions of synthesis based on ontological and epistemological principles and rules. This paper is not about theory testing, but rather about considering the possibility of using the Intergovernmentalist theoretical framework to explore deepening cooperation on security and integration in the defence domain at the European Union's level with some limitation factors which meanwhile were given by the academic community. Bearing in mind that the academic literature that belongs to the Intergovernmentalism Theoretical Framework usually do not cover defence matters, but gives priority to economic interests, it was, therefore, difficult to apply this theoretical approach to the European Union's cooperation on defence and integration in the defence domain. However, there are a few exceptions to the above statement. One of them is a research work done by Dover where he utilizes the Liberal Intergovernmentalism '... to provide the frameworkaround whichexplanations for why the British government sought to Europeanizetheir defence policy - something that most commentators would have judged unthinkable given the transatlanticist preferences of the British government since 1945' (Dover, 2007. p. 3).

This paper consists of five sections. After the introductory remarks, the second section presents the Intergovernmentalist Theoretical Framework as a tool for theorising the European Union - intergovernmentalism, liberal intergovernmentalism and new intergovernmentalism. The intergovernmental and supranational dimensions of the European Union's cooperation on defence and integration in the defence domain are elaborated in the third section representing the main actors within the European Union, such as the European Council, the Council, the European Commission and the European Parliament. The strengthening cooperation on defence and integration in the defence domain - the European Union vis-à-vis the Member States are presented in the fourth section emphasizing the role of the most powerful Member States and the European Union's intergovernmental and supranational bodies. This is followed by a conclusion.

\section{INTERGOVERNMENTALIST THEORETICAL FRAMEWORK AS A TOOL FOR THEORISING THE EUROPEAN UNION}

The European Union as one of the most important and complex creations in contemporary world politics poses demanding challenges for 
scholars to explain the European nature of integration in a comprehensive and objective way. Theorising the European Union using different theoretical frameworks has been topical since the idea of European integration was born. As mentioned in Rosamond (Rosamond, 2000, p. 1) '... the emergence and development of the institutions of economic integration in Western Europe after the Second World War provided a valuable site for both the application of existing theories and the development of new perspectives'. Scholars interested in studying European integration have the possibility to use, evaluate and develop a pretty dispersed theoretical framework based on several main theories such as federalism, functionalism, institutionalism, intergovernmentalism and constructivism, including also their successive theories. The bulk of the literature on theories of European integration focuses on the popular conclusion that the European Union and ongoing processes are too complex to be explained completely by a single theoretical approach, referring to the one well-known story of the blind men and elephant emphasized in the paper OfBlind Men, Elephants and International Integration written by Donald Puchala (Puchala, 1972). ${ }^{4}$ It means that no theory can completely explain the substance and further development of the European Union's cooperation on defence and integration in the defence domain. In other words, there is a need for using eclecticism as a conceptual approach where is it possible due to ontological and epistemological bases.

In this paper, there is no intention to examine and evaluate mentioned theories respectively, yet only to present in general the possibility of using the Intergovernmentalist Theoretical Framework to explain the recent deepening of the European Union's cooperation on defenceand integration in the defence domain for the following reasons. First, the mentioned theoretical framework is arguing for state primacy and state-centric formulations, which is important due to the fact that the Member States are

\footnotetext{
${ }^{4}$ In the paper named Of Blind Men, Elephants and International Integration, Puchala wrote the following observation: 'The story of the blind men and the elephant is universally known. Several blind men approached an elephant and each touched the animal in an effort to discover what the beast looked like. Each blind man, however, touched a different part of the large animal, and each concluded that the elephant had the appearance of the part he had touched .... The total result was that no man arrived at a very accurate description of the elephant. Yet, each man had gained enough evidence from his own experience to disbelieve his fellows and to maintain a lively debate about the nature of the beast.' (Puchala, 1972, p. 267)
} 
not eager to hand over decisions on defence matters considering that this is one of the highest areas of sovereignty. On the other hand, despite the mentioned approach related to sovereignty, as pointed out by Puchala 'some intergovernmentalists scholars see the terms of international cooperation as reflecting the relative bargaining power of different governments, who, while never abnegating their sovereignty, may be willing to pool or delegate it as efficiency and effectiveness require' (Puchala, 1999, p. 319). Also, in accordance with observations taken within the Intergovernmentalist Theoretical Framework, we can conclude that the powerful Member States are more influential than European Union's institutions when we are talking about moving the defence integration agenda forward.

Second, the bulk of the recent literature on the European Union's cooperation on defence and integration in the defence domain focuses on the fact that the Common Foreign and Security Policy and its part the Common Security and Defence Policy are regarded as intergovernmental, while policymaking procedures related to these domains are grounded in specific Treaty provisions remaining in the hands of the Member States (Strikwerda, 2019, pp. 1-2). Put another way, the European Union's legislative framework, primarily part of The Treaty on European Union related to the specific provisions on the Common Foreign and Security Policy and established procedures, set boundaries for further cooperation and deepening integration in the defence domain.

Third, The European Union's defence integration has pretty lagged behind in comparison with integration in the economic, monetary and legal domains. In such a view, broadly understood, there are three main functions of the European integration theories - explanatory/understanding, analytical/descriptive and critical/normative, which run roughly parallel to their three main phases of development - explaining integration, analysing governance and constructing the European Union (Wiener\&Diez, 2009, pp. 6-18). This pattern is very important due to the fact that the Intergovernmentalist Theoretical Framework is primarily exploring the European integration in the early stage based on milestone events and important arrangements.

Fourth, although the European integration theory has been transformed significantly in the recent period (Pollack, 2005) - the long-standing neofunctionalist-intergovernmentalist debate goes in favour of a rationalistconstructivist debate reflecting broader developments in international relations theory; the application of international relations theory has been rejected in favour of comparative politics approaches which analyse the EU 
using off-the-shelf models of legislative, executive, and judicial politics in domestic politics; and considering the EU as an emerging system of multilevel governance in which national governments are losing influence in favour of supranational and sub-national actors, raising important normative questions about the future of democracy within the EU, the Intergovernmentalist Theoretical Framework is still valid and has significant explanatory power to successfully describe processes or events or predict the consequence of these processes or events. Liberal intergovernmentalism which presents a cornerstone of the Intergovernmentalist theoretical framework, in accordance with observations taken by Moravcsik (Moravcsik, 2018), retains its place as a baseline European integration theory.

Fifth, the Intergovernmentalist Theoretical Framework is open to dialogue and synthesis with other European integration theories. From this vantage point, Moravcsik correctly observed that '... reason why liberal intergovernmentalism is open to such a synthesis is that it itself is a synthesis of rationalist theories: it combines theories of preference formation, bargaining, and institutions' (Moravcsik, 2009, p. 84).

Intergovernmentalism, liberal intergovernmentalism and new Intergovernmentalism represent similar and successive concepts based on close assumptions with the possibility to consider within one unique Intergovernmentalism Theoretical Framework with some small-scale constraints. One of the creators and the main proponent of Intergovernmentalism was Stanley Hoffmann, professor at Harvard University. To systematically question neofunctionalist assumptions, his central claim is the following: the nation-state is far from being obsolete, had proven 'obstinate'. As Hoffmann noticed (Hoffmann, 1966, p. 863), political unification within Western Europe could have succeeded if, on the one hand, Western European nations had not been caught in the whirlpool of different concerns, as a result of both profoundly different internal circumstances and outside legacies, and if, on the other hand, they have been able or obliged to concentrate on 'community-building' to the exclusion of all problems situated either outside their area or within each of them.

From this vantage point, Hoffmann has made three remarks and one of them, which concerns the meaning of integration, is especially important and useful for this paper. In short, he concluded that it is 'possible for scholars to argue both that integration is proceeding and that the nationstate is more than ever the basic unit without contradicting each other, for recent definitions of integration "beyond the nation-state" point not toward the emergence of a new kind of political community, but merely toward an 
obscuring of the boundaries between the system of international organization and the environment provided by member states' (Hoffmann, 1966, p. 908). Further, as observed by Howorth (Howorth, 2017, p. 344), integration could only take place in policy areas where states' gains constantly outweighed losses and it means that the integration process would not and could not be the case in the area of the high politics of which defence was the ultimate example.

Furthermore, based on Intergovernmentalism, Andrew Moravcsik presented a new theoretical concept named Liberal intergovernmentalism, which goes a step further in comparison with classical Hoffmann's approach because it rejects the intergovernmentalist position that states will not transfer power to the institutions of the European Union and believes that limiting their sovereignty is a better strategy to retain autonomy than to remain outside the European Union. The central argument of Moravcsik liberal intergovernmentalism is as follows:

'European integration can best be explained as a series of rational choices made by national leaders. These choices responded to constraints and opportunities stemming from the economic interests of powerful domestic constituents, the relative power of each state in the international system, and the role of international institutions in bolstering the credibility of interstate commitments' (Moravcsik, 1998. p. 18).

It means that liberal intergovernmentalism rests on two basic assumptions about politics - the first is that states are actors and the second one is that states are rational. In short, Moravcsik proposed a rationalist framework for international cooperation, which consists of three stages or the specific tripartite sequence as follows: (1) national preference formation; (2) interstate bargaining; (3) institutional choice. Specifically, in explaining national preferences, the main proponent of liberal intergovernmentalism assesses the relative importance of geopolitical interests and economic interests. In explaining interstate bargaining, he assesses the relative importance of interstate bargaining power and the intervention of supranational entrepreneurs. And finally, in explaining the choices to delegate sovereignty to international institutions, the relative importance of federalist ideology, technocratic information management, and the desire for credible commitments were assessed. Each stage is separate, and each stage is explained by a separate theory to distinguish more rigorously between those theories that are substitutes (to explain the same stage of the negotiation) and those that are complements (to explain the different stages of the negotiation) (Moravcsik, 1998, pp. 20; 23-24). 
Moravcsik (1998, p. 24) defined national preferences as an ordered and weighted set of values placed on future substantive outcomes, often termed 'states of the world', that might result from the international political interaction and reflects the objectives of domestic groups that influence the state apparatus. ${ }^{5}$ Different from intergovernmentalism, Moravcsik incorporated the liberal model of preference formation, whereby national governments have a strong idea of what their preferences are and pursue them in bargaining with the other Member States. ${ }^{6}$ Moravcsik evaluated theories based on geopolitical and economic interests in order to explain variation in national preferences. Thus, in this stage, Moravcsik posed the following theoretical question - How much do security externalities and endogenous commercial policy contribute to an explanation of national preferences for international economic policy coordination (Moravcsik, 1998. p. 19)? In order to provide an objective and appropriate answer to this question and using a framework that consists of the two pillars of interests - geopolitical (security externalities) and political-economic assumptions were tested in five cases or five grand bargains. ${ }^{7}$ Following conclusions from the mentioned methodological framework, Moravcsik (Moravcsik, 1998, pp. $473,477)$ correctly observed that '...The bulk of the existing literature claims that the European Community was founded primarily to address real and

${ }^{5}$ In line with Moravcsik's theoretical framework, 'states of the world' means that states seek to realize through world politics-are shaped through contention among domestic political groups (Moravcsik,1998, p.22).

${ }^{6}$ In accordance with observations taken by Rosamond (Rosamond, 2000, p. 135) ,Moravcsik's analysis of the origins of the Single European Act presented in the paper Negotiating the Single European Act is consistent with some of the ideas developed by Bulmer related to the claim that the national polity is the source of legitimacy for state actors (in paper Domestics Politics and European Community Policy-Making). From this vantage point, Moravcsik presents a departure from classic to liberal intergovernmentalism, which means that national interests are best viewed as consequences of a state-society interaction.

${ }^{7}$ All approaches and alternatives in his book The Choice for Europe - Social Purpose and State Power from Messina to Maastricht, Moravcsik tested in five cases/bargains which represent the milestones in the process of development of the European Union: (1) the European Community Treaty - 1957; (2) the consolidation of the European Economic Community and construction of the Common Agricultural Policy - the 1960s; (3) the Creation of the European Monetary System - 1979; (4) the Single European Act - 1986; and (5) the Maastricht Treaty on European Union $-1991$. 
perceived geopolitical threats or to realize federalist ideas. Yet each of the five cases confirms that the most persistent and powerful source of varying national preferences concerning integration over the past four decades has been economic, in particular commercial, interest.' Though, 'yet we should not neglect geopolitical interests and ideas altogether. Over the past forty years their impact on European integration, though clearly secondary, has nonetheless been significant'.

In the second stage of his theoretical work named Interstate Bargaining: Explaining Efficiency and Distribution (Moravcsik, 1998. p. 19), Moravcsik raised the question - How much do political entrepreneurship and asymmetrical interdependence contribute to the efficiency and distributional outcomes of interstate bargaining? To explain the efficiency and distributional outcomes of negotiations, Moravcsik (Moravcsik, 1998. pp. 5467) evaluated two different theories: supranational bargaining theory (based on influence through persuasive information and ideas) and intergovernmental bargaining theory (based on influence through asymmetrical interdependence). Using a theoretical framework which consists of several different dimensions such as the underlying distribution of information and ideas, negotiation process and outcomes, and efficiency and distribution, Moravcsik (1998. p. 485) pointed out that intergovernmental bargaining theory is decisively confirmed while supranational entrepreneurs have only a rare and secondary impact on the efficiency of negotiations.

Finally, we can turn to the third analytical stage within Moravcsik's rationalistic framework of international cooperation - institutional choice. In this sense (Moravcsik, 1998. p. 19), his last question is - How much national identity, informational economies of scale and the desire for credible commitments contribute to state decisions to delegate or pool sovereignty in international institutions or, in other words, the choice of the European Community institutions reflected federalist ideology, the need for technocratic management, or an interest in securing credible member state commitments? In accordance with Moravcsik's approach (Moravcsik, 1998, pp. 67-68),constraints on sovereignty can be imposed in two ways - pooling or delegation of authoritative decisions making. There are three plausible explanations for this - the belief in federalist ideology; the need for centralised technocratic management; and the desire for more credible commitments. With testing three theories related to federalist ideology, technocratic management and credible commitments to explain patterns of institutional choice, based on cross-issue and cross-national variation, domestic cleavages and discourse and institutional form, Moravcsik 
(Moravcsik, 1998, p. 489) pointed out that patterns of support for general institutional provisions continued to reflect federalist ideology.

In sum, Moravcsik (Moravcsik, 1998, p. 472; 2009, p. 69) concluded that 'European integration can best be understood as a series of rational choices made by national leaders. These choices responded to the constraints and opportunities stemming from the economic interests of powerful domestic constituents, the relative power of states stemming from asymmetrical interdependence, and the role of institutions in bolstering the credibility of interstate commitments'. As mentioned in Moravcsik (Moravcsik, 2018, p.1651), following the most political-economy model, liberal intergovernmentalism gives priority to a single issue area while empirically this theoretical approach does not deny that non-issue-specific interest and ideals may have a secondary empirical impact. It leaves them to other theories.

Analysing the post-Maastricht period, proponents of new intergovernmentalism noticed one paradox (Bickerton, Hodson\&Puetter, 2015, p. 705, 708) - 'Member states pursue more integration but stubbornly resist further supranationalism' and apart from that through further elaboration they concluded that nation-states in Europe become the Member States which paved the way for intergovernmental cooperation rather than delegation to supranational institutions. In their research, they set out six hypotheses related to new intergovernmentalism. Bearing in mind that some of these hypotheses have been used in the preparation of this paper, we believe that it is necessary to list them here to provide amore useful theoretical framework. These are the following hypotheses (Bickerton, Hodson\&Puetter, 2015, pp. 711-717) -(1)deliberation and consensus have become the guiding norms of day-to-day decision making at all levels; (2) supranational institutions are not hard-wired to seek ever-closer union; (3) where delegation occurs, governments and traditional supranational actors support the creation and empowerment of de novo bodies; (4) problems in domestic preference formation have become standalone inputs into the European integration process; (5) the differences between high and low politics have become blurred; and (6) the EU is in a state of disequilibrium.

\section{INTERGOVERNMENTAL AND SUPRANATIONAL DIMENSIONS OF THE EUROPEAN UNION'S COOPERATION ON DEFENCE AND INTEGRATION IN THE DEFENCE DOMAIN}

The Common Foreign and Security Policy (CFSP), including also the Common Security and Defence Policy (CSDP), emanated from the Treaty 
of Maastricht adopted in December 1991. In line with the foundations of the Treaty of Maastricht and the Saint-Malo Declaration signed in December 1998 by the Governments of France and the United Kingdom, the European Council in June 1999 launched the European Security and Defence Policy (ESDP), which was renamed the Common Security and Defence Policy ten years later by the Treaty of Lisbon in December 2009.

Furthermore, related to the process of building military assets, as noticed by Glišić, Stojković and Lađevac, the Bosnian War was a history-making moment for further development of the capabilities and international tools for crisis management (Glišić, Stojković\&Lađevac, 2019, pp. 339-340). Based on negative experience from the Bosnian War, related to the insufficient military capabilities, the European Union approved the 1999 Helsinki Headline Goal calling the EU's Member States to be able by 2003 to deploy up to 15 brigades or 60.000 soldiers within 60 days and for at least one year. Due to the fact that the 1999 Helsinki Headline Goal was unachievable in 2004, the European Union adopted the 2010 Headline Goal with a focus on interoperability, deployability, and sustainability, including also the creation of the EU's Battle groups.

In addition, the Lisbon Treaty dated 1 December 2009, as the main milestone, provided the legal framework for deepening cooperation in the area of security and defence thanks to the several relevant clauses. In December 2013, for the first time since the entry into force of the Lisbon Treaty, the European Council discussed defence cooperation within the European Union and identified priorities for deepening this kind of cooperation. Finally, A Global Strategy for the European Union's Foreign and Security Policy with the aim to steer the Union's global action and set priorities to protect EU citizens while promoting the Union's interests and universal values was presented by the EU High Representative to the European Council in June 2016 (European External Action Service, 2016). The European Council welcomed the presentation of the EU's Global Strategy and invited the High Representative, the European Commission, and the Council to take the work forward to implement in practice this strategic document (Glišić, Đorđević\&Stojković, 2020, pp. 287-299).

Speaking about intergovernmental and supranational dimensions of the European Union's cooperation on defence matters, within the wording given by the Intergovernmentalists Theoretical Framework, it should be noted that the Treaty on European Union anticipates that competences not conferred upon the Union in the Treaties remain with the Member States, and national security remains the sole responsibility of each Member State 
(European Union, 2016, Articles 4.1 and 4.2). Furthermore, as foreseen in Article 31.1 of the Treaty on European Union, decisions related to the Common Foreign and Security Policy shall be taken by the European Council and the Council of Ministers of the European Union acting unanimously, except where this Chapter provides otherwise. Decisions having military or defence implications must be made unanimously. It means that constraints on the sovereignty of Member States cannot be imposed in the Common Security and Defence Policy, including also domain-related on the European Union's cooperation on defence and integration in the defence domain. Taking into account the scope and aim of this paper, the question of sovereignty within European integration merits brief elaboration. In accordance with the established European Union's legal system and decision-making procedures, constraints on sovereignty can be imposed in two ways: pooling - when governments agree to decide future matters by voting procedures other than unanimity; or delegation of authoritative decision-making - when supranational actors are permitted to take certain autonomous decisions, without an intervening interstate vote or unilateral veto (Moravcsik, 1998, pp. 67-68).

On the other hand, the Common Security and Defence Policy (CSDP), as a part of the Common Foreign and Security Policy (CFSP), is a MemberState-driven process primarily on a bilateral base using the appropriate European Union's framework established on an intergovernmental base. It is very important to emphasize that the European Union's competence in matters of the CFSP shall cover all areas of foreign policy and all questions relating to the security, including the progressive framing of the Union's common defence policy that might lead to a common defence (European Union, 2016a, Article 24.1). Also, as predicted in the Treaty on European Union, the Member States which wish to establish enhanced cooperation between themselves within the framework of the Union's non-exclusive competences may make use of its institutions and exercise those competences by applying the relevant provisions of the Treaties (European Union, 2016a, Article 20.1). In this sense, the European Council and the Council of the European Union provide the strategic setting for the Commons Security and Defence Policy.

The European Council has been formalized on 9 December 1974 from a process based on European summitry, which emerged in the 1960s and 1970s with enhancing the role of heads of state and government. This highest body within the European structure sets the EU's Common Foreign and Security Policy and the Common Security and Defence Policy. As noticed 
by Luis Amorim, the European Council has always been particularly attentive to the CFSP matters, including the CSDP (Amorim, 2017, p. 47). According to Article 26.1 of the Treaty on European Union, the European Council identifies the Union's strategic interests, determines the objectives of and defines general guidelines for the common foreign and security policy, including for matters with defence implications, and adopts the necessary decisions. Furthermore, as foreseen in Article 42.2 of the Treaty on European Union, the Common Security and Defence Policy shall include the progressive framing of a common European Union's defence policy which will lead to a common defence, when the European Council, acting unanimously, so decides. In this case, the European Council recommends to the Member States the adoption of such a decision in accordance with their respective constitutional requirements.

Recently, within the presented legal framework, the European Council has taken several very important decisions to strengthen the European Union's cooperation on defence and integration in the defence domain. In December 2013, for the first time since the entry into force of the Lisbon Treaty, the European Council discussed defence cooperation within the European Union and identified priorities for deepening this kind of cooperation in three main areas: increasing the effectiveness, visibility and impact of the CSDP; enhancing the development of capabilities; and strengthening Europe's defence industry (European Council, 2013, paragraphs 5-21). ${ }^{8}$ Besides that, A Global Strategy for the European Union's Foreign and Security Policy with the aim to steer the Union's global action and set priorities to protect EU citizens while promoting Union's interests and universal values was presented by the EU High Representative to the European Council in June 2016 (European External Action Service, 2016). Owing to that, the same year in December, in order to strengthen the European Union's cooperation on defence, the European Council gave priority to the implementation of the Global Strategy in the area of security and defence and to establish the European Defence Action Plan (European Council, 2016, paragraphs 11-12). In June 2017 the European Council decided to launch or to wake up the 'sleeping beauty' of the Lisbon Treaty

\footnotetext{
${ }^{8}$ The Treaty of Lisbon includes the following relevant clauses for defence issues: the Enhanced Cooperation Clause (Article 20 TEU), the Solidarity Clause (Article 222 TFEU), the Flexibility Mechanism (Article 44 TEU), the Mutual Assistance Clause (Article 42.7 TEU), and the most powerful mechanism the Permanent Structured Cooperation (Article 46 TEU).
} 
- the Permanent Structured Cooperation (PESCO) to strengthen the European Union's security and defence. In this sense, the European Council invited the Member States to agree on a common list of criteria and commitments, together with concrete capability projects, in order to start this cooperation (European Council, 2017, paragraph 8).

In line with Article 26.2 of the Treaty on European Union, the Council of the European Union (shorter Council) shall frame the common foreign and security policy and take the decisions necessary for defining and implementing it on the basis of the general guidelines and strategic lines defined by the European Council. The Council is an intergovernmental decision-making body that routinely legislates by a qualified majority vote with an exception where the Treaties provide otherwise, such as in the CFSP/CSDP domains which require consensus and unanimity. Within the Foreign Affairs configuration (the Foreign Affairs Council), the Council also brings together defence ministers and they usually meet back-to-back with foreign ministers.

The Council has taken substantive decisions since 2016 with a significant impact on deepening the European Union's cooperation on defence and integration in the defence domain. Conforming to the guidance given by the European Council, the European Union's foreign and defence ministers in November 2016 set the framework for further development of security and defence policy and adopted the Implementation Plan on Security and Defence, which covers several very important initiatives such as the Permanent Structure Cooperation, the Coordinated Annual Review on Defence, idea related to the establishment of the new organizational unit Military Planning and Conduct Capability, the European Peace Facility, and the Capability Development Plan (Council of the European Union, 2016a\&2016b). In June 2017, the Council adopted the decision establishing the Military Planning and Conduct Capability within the EU Military Staff and under the political control of the Political and Security Committee with responsibility for the operational planning and conduct of non-executive military missions at the strategic level (Council of the European Union, 2017a).In line with the European Council conclusions, in December 2017, the Council adopted the decisions triggering the Permanent Structure Cooperation with the Member States whose military capabilities fulfil higher required criteria and which have made commitments to one another in this area with a view to the most demanding missions, and contributing to the fulfilment of the Union level of ambition while the first initial list of the projects and implementation roadmap were adopted in March 2018 
(Council of the European Union, 2017b, Article 1\& Council of the European Union, 2018). With an aim to provide stronger and more ambitious defence cooperation with partners in the European Union's framework, the Council in November 2020 established general conditions under which non-EU countries can exceptionally be invited to participate in individual PESCO projects (Council of the European Union, 2020).

Apart from the European Council and the Council of the European Union, a few very important initiatives were taken by the European Commission, which in the Common Security and Defence Policy plays the secondary role in comparison with the Member States. However, in the last ten years, the European Commission's engagement within the Common and Security Policy is getting more and more visible. With the aim to create an internal European Union's market for defence material based on the Commission's initiative, the Council adopted the Defence and Security Procurement Directive in July 2009. Further, the European Commission is working hard on the implementation process of the EU Global Strategy in the security and defence domain. As a result, the European Defence Action Plan was launched in November 2016 by the European Commission to support Europe's defence industry and the entire cycle of capability generation, from research and development to production and acquisition through three different pillars: (1) launching a European Defence Fund; (2) fostering investments in defence supply chains; and (3) reinforcing the single European defence market (European Commission, 2016). In summary, as correctly observed by Marrone and Ungaro (Marrone\&Ungaro, 2014. pp. 13-14), the European Commission has progressively extended its footprint on the legislative, economic and industrial side while positioning itself between defence and issues such as internal market, procurement, industrial policies as well as research and innovation.

As foreseen in Article 36 of the Treaty on European Union, the European Parliament may address questions or make recommendations to the Council or the High Representative. Twice a year it shall hold a debate on progress in implementing the Common Foreign and Security Policy, including the Common Security and Defence Policy and adopts reports. Also, based on the declaration made by the High Representative on political accountability in 2010, the Joint Consultation Meetings are organized on a regular basis between the European Parliament and other European Union's institutions related to the CFSP/CSDP domain. It means that the European Parliament has no direct role to influence significantly the Common Security and Defence Policy and the European Union's cooperation on defence and 
integration in the defence domain. Nevertheless, we should emphasize that the political framework for consultation and dialogue has been evolving with the aim to allow and give possibilities for the European Parliament to play a full role in developing the Common Security and Defence Policy.

Without any doubt, the European Council and the Council of the European Union represent purely intergovernmental bodies when taking decisions related to the Common Security and Defence Policy, including also the European Union's cooperation on defence and integration in the defence domain. Mentioned decisions are taken by unanimity with a few exceptions such as matters related to the European Defence Agency and the Permanent Structured Cooperation (European Union, 2016, Articles 45, 46). As opposed, the European Commission is a supranational institution that promotes the general interest of the Union and takes appropriate initiatives to that end.

On the other hand, there are some scholars trying to make a blur between sharp intergovernmentalism and supranationalism boundaries. In short, Goebel (Goebel, 2013) argues that the European Council is intrinsically intergovernmental in structure and partly supranational in executive policymaking and legislative roles, while the Council is also intrinsically intergovernmental in structure, but the blend of intergovernmental and supranational features in executive policy-making and legislative roles. Whereas, the European Parliament is federal in nature, supranational in vision and operations. By the same token, the European Commission is intrinsically supranational both in structure and its operational role.

\section{STRENGTHENING COOPERATION ON DEFENCE AND INTEGRATION IN THE DEFENCE DOMAIN - THE EUROPEAN UNION VIS-À-VIS THE MEMBER STATES -}

National preferences related to the deepening European Union's defence and integration vary among the Member States and depend on politicaleconomic imperatives or issues-specific interdependence based on politicalmilitary threats (Jonson, 2006, pp. 46-47). Before Brexit, three of the most powerful Member States - the United Kingdom, France and Germany had diametrically different national preferences in the mentioned matters. As correctly observed by Moravcsik, Germany is most favourable, France less so and the United Kingdom least so to deepening cooperation in the CFSP domain (Moravcsik, 1998, p. 28). The United Kingdom was the main obstacle for further deepening cooperation on defence and integration in 
the defence domain within the European Union due to the fact that was using the veto consistently to hindered integration in the defence domain.

Apart from this, France and Germany have also different ideas on the role of the military and the use of force. Likewise, their defence priorities, threat perceptions and regional priorities are different. At the European level, France wants the European Union to increase its military capabilities and be ready for use of force and intervention when necessary. On the other hand, due to its history, Germany advocates a different approach, giving primacy to capacity building using the PESCO framework without emphasising operational engagement. As Kempin and Kunz presented in their study 'What remains key to French autonomy is the country's capacity to lead operations on its own and to retain key capabilities allowing to preserve a major influence on operations led with allies' (Kempin\&Kunz, 2017, p.12). Thus, France proposed the European Intervention Initiative in 2017 as a forum of European participating states to engage their military capabilities and forces to protect European security interests and it is neither part of NATO nor the EU. Despite the mentioned differences, in the postBrexit era, Germany and France are able to find a compromise on milestone events to support and reinforce European cooperation on defence and integration in the defence domain. Cooperation in the security and defence domain is becoming the main axes of contemporary French-German relations. Thanks to Germany and France's support in 2017, the Council of the European Union adopted the decision triggering the Permanent Structured Cooperation and the decision establishing the Military Planning and Conduct Capability. Also, common funding for the EU Battle groups is provided. Apart from the mentioned, the focus of the Franco-German European agenda has concentrated on the implementation process of the Coordinated Annual Review on Defence and on establishing the European Defence Fund.

Analysing German defence policy, especially the last published White Paper on German Security Policy and the Future of the Bundeswehr (Federal Ministry of Defence, 2016, p. 49; 129), it can be seen that one of Germany's strategic priorities is defined as 'Strengthening the cohesion and capacity to act of NATO and the European Union'. Also, in order to fulfil the interoperability gap between European Armed Forces, the Europeanization of defence is seen as one of the most important content within the armament acquisition process. It can be said that Germany has a long term objective to be a very active player in the process of strengthening the European Union's cooperation on defence and integration in the defence domain. Thus, during 
Germany's Presidency of the Council of the European Union in the period from 1 July to 31 December 2020, significant progress related to the cooperation on defence and integration in the defence domain has been achieved. It is worth mentioning that Germany within the interstate bargaining process found the optimum way to speed up European cooperation on defence and integration in the defence domain using the Permanent Structured Cooperation, and made all necessary conditions for under which third States could be invited to participate in individual projects within this framework. What is more, Germany also made success and reached a provisional agreement on setting-up the European Defence Fund in the context of the Multiannual Financial Framework for 2021-2027. Also, in December 2020, the Council reached a political agreement on the European Peace Facility to finance the external action having military or defence implications under the Common Foreign and Security Policy. Given the above-mentioned, it can be said in conclusion that one of the assumptions which belong to the Intergovernmentalist Theoretical Framework is confirmed - the powerful Member States are more influential than European Union's institutions when we are talking about moving the defence integration agenda forward. Apart from France and Germany, the sum of similar or common national preference of the medium and small Member States, although unable to make significant progress without the commitment of the above-mentioned two states, can provide the critical mass to trigger some processes and initiatives to strengthen the European Union's cooperation on defence and integration in the defence domain.

The EU's Member States are still the key players in the domain of the Common Security and Defence Policy, and also in the domain related to the European Union's cooperation on defence and integration in the security domain. In line with the legislative framework of the European Union, the Common Security and Defence Policy and also strengthening the European Union's cooperation on defence and integration in the defence domain remain subjects of the unanimity role. However, to some extent in the contemporary circumstances, as presented in Rosamond (Rosamond, 2000. p. 144) 'the preferences of institutions also figures as an important variable influencing the style and substance of intergovernmental bargaining'. Likewise, we can see that some scholars claim that the reality is far more complex, especially when they evaluate the decision-shaping process and decision-making process within the European Union. Thanks to the Lisbon Treaty, the High Representative of the European Union for Foreign Affairs and Security Policy (High Representative) is well-powered to bring to the table a politico-strategic approach able to balance both EU-centred - 
neofunctionalist view and state-centred - intergovernmental view, by relying on the European Defence Agency (EDA), the European External Action Service including EU Military Committee (EUMC) and EUMilitary Staff (EUMS), as well as the coordinating role within the European Commission (Marrone\&Ungaro, 2014). The presented approach creates a fertile ground for deepening the boundary between the decision-shaping process and decision-making process. Also, the fact that decision-shaping process within the Common Security and Defence Policy is becoming more and more supranational taking into consideration engagement of different European Union's bodies, and some of them are already mentioned such as the EDA, the EUMC and the EUMS along with national representatives engaged in different working groups and committees. Consequently, as noticed by Howorth (Howorth, 2012. p. 433-434), '... scholars wonder whether we are not in fact witnessing the disappearance of any meaningful dichotomy between intergovernmentalism and supranationalism', and this is very important due to the fact that working groups and committees represented by national representatives are 'acting in a mode which is as close tosupranational as it is to intergovernmental'. In order to explain new trends related to the decision-shaping and decision-making process in the Common Security and Defence Policy, Howorth coined anew theoretical approach 'supranational intergovernmentalism' (Howorth, 2000).

Based on the former review of the intergovernmental and supranational dimension of the European Union's cooperation on defence and integration in the defence domain, it can be said that the Member States have primacy in comparison with the European Union's institutions and agencies. In order to protect national sovereignty all decisions related to the security and defence domains must be made using the principle of unanimity. Having in mind security and defence matters, the European Council and the Council of the European Union, with their legislative procedures, are providing a purely intergovernmental framework for the decision-making process. One of the most important defence matters for discussions within the European Council and the Council was the Permanent Structured Cooperation. The PESCO represents a powerful tool for deepening European cooperation on defence and integration in the defence domain. Taking into account the preservation of sovereignty, it is very important to emphasize that participation in individual projects within the PESCO is voluntary and leaves national sovereignty untouched based on the intergovernmental agreements in which the Member States represent key players. 
Within the European Commission as an intrinsically supranational framework, slightly different trends can be noticed. First, as observed by Strikwerda (Strikwerda, 2019, p. 49), the Defence and Security Procurement Directive represents the first supranational policy within the Common Security and Defence Policy. Also, the mentioned directive has triggered processes which are more EU-centred and market oriented in comparison with the intergovernmental and state-centric approach. Second, it is well known that European military spending has been decreasing after the Cold War, particularly with regard to research and development activities, and also defence industry continues to be fragmented on a national basis. At the same time, the European defence industry remains a crucial asset for the European Union's economy which should be reinforced by the EU's Defence Technological and Industrial Base and through new financial incentives. Within given circumstances, the European Commission launched at the end of 2016 the European Defence Fund which consists of two complementary parts or popularly named 'windows': (1) A 'research window' to fund collaborative defence research projects at the EU's level; and (2) A 'capability window' to support the joint development of defence capabilities commonly agreed by the Member States (European Commission, 2016, pp. 5-6). In order to support presented initiatives within the European Commission's structure, a new body was established in January 2020 - the DirectorateGeneral for Defence Industry and Space.

Mentioned trends related to defence matters within the European Commission merit brief explanations on the following. First, the Member States still have the possibility to use the European Council and the Council as the intergovernmental frameworks to agree and adopt all the important initiatives related to the European Union's cooperation on defence and integration in the defence domain. This is especially important when we are talking about initiatives within the possibilities of Enhanced cooperation procedure (European Union, 2016a, Article 20) and about decision-making procedures which should be used in this case (European Union, 2016b, Article 329.2). Second, following the national preferences, the Member States through interstate bargaining supported both mentioned initiatives in order to provide better conditions for national small and medium enterprises that produce military weapons and equipment and also the defence industry as a whole. It is obvious that here we can implement national preferences formation on way proposed within Liberal Intergovernmentalism which emphasize that national interests are best viewed as consequences of a statesociety interaction. In line with Liberal Intergovernmentalism, in this case, the political economy of defence is getting more and more important by 
examining the interplay between the fiscal and economic environment that constrains defence spending, domestic politics, and how these relationships influence military procurement and the defence industrial base (Stone\&Solomon, 2020). In addition to the above, the cost of current fragmentation and inefficiencies related to the European Union's Defence Technological and Industrial Base is high, even though the defence expenditures of the EU's Member States had a positive trend in the last five years from 156 to 186 billion Euros (European Defence Agency, 2021, p. 4). The European Defence Fund in the given circumstances is getting more and more important to reinforce the Defence Technological and Industrial Base and also for further strengthening the European Union's cooperation on defence and integration in the defence domain. The mentioned trend for further improvement of the EU's Defence Technological and Industrial base is very important for non-NATO members (Stojković\&Glišić, 2020, pp. 594597) and therefore for a broader approach to analyse the interstate bargain process. And third, the European Defence Agency is one of the main actors in implementing the Defence and Security Procurement Directive and the European Defence Fund. The role of the European Defence Agency has increased in the last years thanks to the exploiting its dual nature as an intergovernmental organization (largely dependent on the interests of the Member States) and the European Union's actor, fully part of the European institutional framework (Marrone\&Ungaro, 2014, p. 5).

\section{CONCLUSION}

It can be concluded that strengthening the European Union security and defence, primarily the European Union's cooperation on defence and integration in the defence domain affects possible shifting preferences between supranationalism and intergovernmentalism by reinforcing the role of the Member States, especially the most powerful. Almost all new initiatives and mechanisms triggered to strengthen the European Union's cooperation on defence and integration in the defence domain are in the hands of the Member States. In other words, the Member States represent the central decision-makers within the processes related to the defence matters within the European Union.

Using the Intergovernmentalist Theoretical Framework and analysing data from a lot of different documents and academic literature, the paper answers the research question related to a possible decline in the importance of the supranationalism in relation to the intergovernmentalism within the 
process of strengthening the European Union's cooperation on defence and integration in the defence domain and also demonstrates how the mentioned process is possible if the important Member States have positive and strong intention to cooperate on defence matters.

A lot of stakeholders are presented within the implementation process of the EU's Global Strategy and therefore in the process of strengthening EU's cooperation on defence and integration in the defence domain. Certainly the most important are the Member State bargaining primarily in the intergovernmental frameworks - the European Council and the Council, the European Commission and its agencies. So far, in the process of strengthening the European Union's cooperation on defence and integration in the defence domain, the Member States have primacy in developing initiatives based on intergovernmental nature - for example, the Permanent Structured Cooperation, while the European Commission initiatives aimed to reinforce supranational character in defence matters, such as the Defence and Security Procurement Directive and the European Defence Fund.

Taking into account the intergovernmental and supranational dimension related to defence matters at the European level, it can be said that the Member States have primacy in comparison with the European Union's institutions and agencies. However, due to the fact that a lot of bodies from the institutional framework of the European Union are deeply engaged in the decision-shaping process to prepare decision which will be taken in the auspices of the European Council or the Council of the European Union, the clear distinction between intergovernmental and supranational is blurring slowly.

\section{REFERENCES}

Amorim, L. (2017). The European Council and CSDP, in: Rehrl, J. (Ed.), CSDP Handbook. (pp. 46-54). Vienna, Directorate for Security policy of the Federal Ministry of Defence and Sports of the Republic of Austria.

Bickerton, J.C., Hodson, D.\&Puetter, U. (2015). The New Intergovernmentalism: European Integration in the Post-Maastricht Era, Journal of common Market Studies, 53 (4), pp. 703-722.

Council of the European Union. (2016a). Council Conclusions on implementing the EU Global Strategy in the area of Security and Defence, Council of the European Union, Brussels. 
Council of the European Union. (2016b). Implementation Plan on Security and Defence, Council of the European Union, Brussels.

Council of the European Union. (2017a). Council Decision (EU) 2017/971. Official Journal of the European Union.

Council of the European Union. (2017b). Council Decision (CFSP) 2017/2315 establishing permanent structured cooperation (PESCO) and determining the list of participating Member States.Official Journal of the European Union.

Council of the European Union. (2018). Council Recommendation concerning a roadmap for the implementation of PESCO, Council of the European Union, Brussels.

Council of the European Union. (2020). Council Decision (CFSP) 2020/1639establishing the general conditions under which third States could exceptionally be invited to participate in individual PESCO projects. Official Journal of the European Union.

Dover, R. (2007). Europeanization of British Defence Policy. Hampshire, Asghate Publishing Limited.

Erdem, I.E. (2006). European Integration and International Relations Theory. SSRN Electronic Jorunal, doi: 10.2139/ssrn/2202768, retrieved from: https://www.researchgate.net/publication/254946796_European_Inte gration_and_International_Relations_Theory. Accessed: 15 September 2020.

European Commission. (2016). Communication from the Commission to the European Parliament, the European Council, the Council, the European Economic and Social Committee and the Committee of the Regions. Europe Defence Action Plan. European Commission, Brussels.

European Council. (2013, December 19/20). Council Conclusions EUCO217/13. European Council, Brussels.

European Council. (2016, December 15). Council Conclusions EUCO 34/16. European Council, Brussels.

European Council. (2017). Council Conclusions EUCO 8/17. European Council, Brussels.

European Defence Agency. (2021). Defence Data 2018-2019 - Key findings and analysis. Brussels.

European External Acton Service. (2016). Shared Vision, Common Action: A stronger Europe - A Global Strategy for the European Union's Foreign and Security Policy. European External Action Service, Brussels. 
European Union. (2016a).Consolidated Version of the Treaty on European Union. Official Journal of the European Union.

European Union. (2016b). Consolidated Version of the Treaty on Functioning of the European Union. Official Journal of the European Union.

Federal Ministry of Defence. (2016). White Paper 2016 on German Security Policy and the Future of the Bundeswehr. Berlin.

Glišić, M., Stojković, D.\&Lađevac, I. (2019) NATO Crisis Management Concept: Twenty Years After the Bombing of the Federal Republic of Yugoslavia, in: Vuković, N.(Ed.), David vs. Goliath: NATO war against Yugoslavia and its implications, (pp. 327-349). Belgrade, Institute of International Politics and Economics \& Faculty of Security Studies at the University of Belgrade.

Glišić, M.,Đorđević, B.\&Stojković, D. (2020). The EU Global Strategy - A Possible Framework for Deepening Cooperation with the Republic of Serbian Defence Domain, in: Jović-Lazić,A.\&Troude, A. (Eds.), Challenges and the Place of the Balkans and Serbia in a Changing World, (pp. 284-309). Belgrade, Institute of International Politics and Economics \& Faculty of Security Studies at the University of Belgrade.

Goebel,J. R. (2013). Supranational? Federal? Intergovernmental? The Governmental Structure of the European Union After the Treaty of Lisbon, 20 Colum. J. Eur. L. 77, retrieved from https://ir.lawnet.fordham.edu/ faculty_scholarship/577. Accessed 29 November 2020.

Hoffmann, S. (1966). Obstinate or Obsolete? The Fate of the Nation-State and the Case of Western Europe. Daedalus, 95(3), pp. 862-915. Retrieved from http:/ / www.jstor.org/stable/20027004. Accessed 25 January 2021.

Howorth, J. (2000). European Integration and Defence: the ultimate challenge?, Chaillot Papers, 43, Paris, Institute for Security Studies.

Howorth, J. (2012). Decision-making in security and defence policy: Towards supranational inter-governmentalism, Cooperation and Conflict, 47 (4), pp. 433-453.

Howorth, J. (2017).The European Union's Security and Defence Policy: The Quest for Purpose, in: Hill, C.\&Smith, M., Vanhoonacker, S. (Eds.), International Relations and the European Union, (pp. 341-365). Oxford, Oxford University Press.

Jonson, P. (2006). The Development of the European Security and Defence Policy - An Assessment of Preferences, Bargains and Outcomes. Stockholm, FOI - 
Swedish Defence Research Agency, retrieved from https:/ / www.foi.se/ rest-api/report/FOI-R-1967-SE. Accessed 29 November 2020.

Kempin, R.\&Kunz, B. (2017). France, Germany, and the Quest for European Strategic Autonomy - Franco-German Defence Cooperation in A New Era. German Institute for International and Security Affairs \&The Study Committee on French-German Relations, retrieved from: https:// www.ifri.org/en/publications/notes-de-lifri/notes-cerfa/francegermany-and-quest-european-strategic-autonomy-franco. Accessed 29 November 2020.

Marambanyika, O. (2018). Why is European Union Defence Integration Difficult to Achieve? Gothenburg, University of Gothenburg, retrieved from https://gupea.ub.gu.se/bitstream/2077/56819/1/gupea_2077_56819_ 1.pdf. Assessed 21 October 2020.

Marrone, A.\&Ungaro, R.A. (2014). Actors in the European Defence Policy Area: roles and developments. Instituto Affari Internacionali\& Centro Studisul Federalismo, retrieved from http:// www.iai.it/sites/default/files/csfiai_defenceactors.pdf. Assessed 29 November 2020.

Moravcsik, A. (1998). The Choice for Europe - Social Purpose and State Power from Messina to Maastricht. Ithaca, Cornell University Press.

Moravcsik, A. (2018). Preferences, Power and Institutions in $21^{\text {st }}$ - century Europe, Journal of common Market Studies, 56(7), pp. 1648-1674.

Moravcsik, A.\&Schimmelfennig, F. (2009). Liberal Intergovernmentalism, in: Wiener, A.\&Diez, T. (Eds.), European Integration Theory (pp. 67-87). Oxford, University Press.

Pollack A.M. (2005). Theorizing the European Union: International Organizaton, Domestic Polity, or Experiment in New Governance? Annual Review of Political Science, 8, pp. 357-398.doi.org/10.1146/annurev.polisci. 8.082 103.104858, retrieved from https:/ / www.annualreviews.org/doi/pdf/ 10.1146/annurev.polisci.8.082103.104858. Accessed 15 September 2020.

Puchala, J.D. (1972). Of Blind Man, Elephants and International Integration, Journal of common Market Studies, 10 (3), pp. 267-284.

Puchala, J.D. (1999). Institutionalism, intergovernmentalism and European integration: A review article, Journal of common Market Studies, 37 (2), pp. 317-331.

Rosamond, B. (2000). Theories of European Integration. New York, St. Martin's Press. 
Stojković, D.\&Glišić, M. (2020). Serbia's Military Neutrality: Is It Economically Beneficial? Defence and Peace Economics, 31 (5), (pp. 583599), DOI: 10.1080/10242694.2018.1547952.

Stone, J.C.\&Solomon, B. (2020). The Political Economy of Defence, in: Juneau, T. Lagasse, P.\&Vucetic, S. (Eds), Canadian Defence Policy in Theory and Practice, (pp. 135-158). Palgrave, retrieved from https://doi.org/ 10.1007/978-3-030-26403-1.

Strikwerda, J. (2019). Integration in the European Union's Field of Defence and Security. Oslo, Centre for European Studies - University of Oslo, retrieved from https://www.sv.uio.no/arena/english/research/ publications/arena-reports/2019/report-0219-strikwerda-uten-art.3.pdf. Accessed 2 October 2020.

Wiener, A.\&Diez, T. (2009). Introducing the Mosaic of Integration Theory, in: Wiener, A.\&Diez, T. (Eds.), European Integration Theory (pp. 1-22). Oxford, University Press. 